
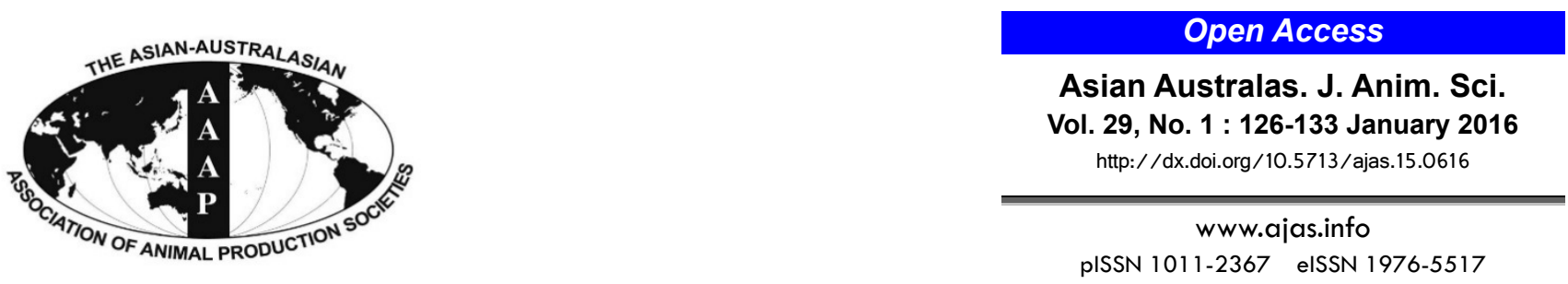

\title{
Cloning and Characterization of an Endoglucanase Gene from Actinomyces sp. Korean Native Goat 40
}

\author{
Sung Chan Kim ${ }^{1}$, Seung Ha Kang ${ }^{2}$, Eun Young $\mathrm{Choi}^{3}$, Yeon Hee Hong, Jin Duck Bok ${ }^{4}$, \\ Jae Yeong Kim, Sang Suk Lee ${ }^{5}$, Yun Jaie $\mathrm{Choi}^{4}$, In Soon $\mathrm{Choi}^{3}$, and Kwang Keun Cho* \\ Department of Animal Resources Technology, Gyeongnam National University of Science and Technology, \\ Chinju 660-758, Korea
}

\begin{abstract}
A gene from Actinomyces sp. Korean native goat (KNG) 40 that encodes an endo- $\beta$-1,4-glucanase, EG1, was cloned and expressed in Escherichia coli (E. coli) DH5a. Recombinant plasmid DNA from a positive clone with a 3.2 kb insert hydrolyzing carboxyl methyl-cellulose (CMC) was designated as pDS3. The entire nucleotide sequence was determined, and an open-reading frame (ORF) was deduced. The ORF encodes a polypeptide of 684 amino acids. The recombinant EG1 produced in E. coli DH5 $\alpha$ harboring pDS3 was purified in one step using affinity chromatography on crystalline cellulose and characterized. Sodium dodecyl sulfatepolyacrylamide gel electrophoresis/zymogram analysis of the purified enzyme revealed two protein bands of 57.1 and $54.1 \mathrm{kDa}$. The amino terminal sequences of these two bands matched those of the deduced ones, starting from residue 166 and 208 , respectively. Putative signal sequences, a Shine-Dalgarno-type ribosomal binding site, and promoter sequences related to the consensus sequences were deduced. EG1 has a typical tripartite structure of cellulase, a catalytic domain, a serine-rich linker region, and a cellulose-binding domain. The optimal temperature for the activity of the purified enzyme was $55^{\circ} \mathrm{C}$, but it retained over $90 \%$ of maximum activity in a broad temperature range $\left(40^{\circ} \mathrm{C}\right.$ to $\left.60^{\circ} \mathrm{C}\right)$. The optimal $\mathrm{pH}$ for the enzyme activity was 6.0. Kinetic parameters, $\mathrm{K}_{\mathrm{m}}$ and $\mathrm{V}_{\mathrm{max}}$ of $\mathrm{rEG1}$ were $0.39 \%$ CMC and 143 U/mg, respectively. (Key Words: Korean Native Goat, Actinomyces sp., Endo- $\beta$-1,4-glucanase, Cellulase)
\end{abstract}

\section{INTRODUCTION}

There is great interest in using huge amounts of cellulosic biomass, broken down into sugars, as a renewable source. Cellulases have potential applications in various

\footnotetext{
* Corresponding Author: Kwang Keun Cho. Tel: +82-55-7513286, Fax: +82-55-751-3689, E-mail: chotwo2@daum.net

${ }^{1}$ Department of Biochemistry, Institute of Cell Differentiation and Aging, College of Medicine, Hallym University, Chuncheon 200702, Korea.

2 CSIRO Animal, Food and Health Science, Queensland Bioscience Precinct, St. Lucia, QLD 4067, Australia.

${ }^{3}$ Department of Biological Science, Silla University, Busan 617736, Korea.

${ }^{4}$ Institute of Green-Bio Science and Technology, Seoul National University, Pyungchang 25354, Korea.

${ }^{5}$ Department of Animal Science and Technology, Sunchon National University, Sunchon 540-742, Korea.

Submitted Jul. 26, 2015; Revised Oct. 9, 2015; Accepted Nov 14, 2015
}

areas, such as the livestock, food, pharmaceutical, textile, detergent, chemical, and fuel production industries. For efficient biological conversion of cellulosic biomass into value-added products or application of cellulose-degrading enzymes, the molecular cloning of cellulolytic enzyme genes with high activity is of the utmost importance. The bioconversion of cellulose into glucose requires the actions of three types of enzymes: a cellulase enzyme complex, including endo- $\beta-1,4$-glucanase, cellobiohydrolase, and $\beta$ glucosidase (Coughlan, 1985). Among these, endo- $\beta-1,4-$ glucanase (1,4- $\beta$-D-glucan glucanohydrolase; EC 3.2.1.4) attacks cellulose chains at random, breaking internal bonds into smaller fragments, and progressively generating nonreducing ends on which cellobiohydrolase can act. Numerous studies have described endo- $\beta$-1,4-glucanase genes in bacteria and fungi (Gilkes et al., 1991). Members of the industrially important Bacillus also produce endo- $\beta$ 1,4-glucanase, and the genes encoding these enzymes have been cloned and characterized (Lee and Pack, 1988; Baird 
et al., 1990; Lemaire and Beguin, 1993; Miyatake and Imada, 1997). The rumen in ruminants is an especially active site for the fermentation of cellulose. The most abundant cellulolytic ruminal bacteria include Ruminococcus albus, Fibrobacter succinogenes, Ruminococcus. flavefaciens, and Butyrivibrio fibrisolvens (Forsberg, 1993; Malburg and Forsberg, 1993; Sahu et al., 2004). The first isolation and identification of a novel anaerobic cellulolytic Actinomyces sp. from rumen of Korean native goat was reported by Park (Park et al., 1993). This bacterium having high carboxy methyl cellulase (CMCase; endoglucanase) activity was one of the predominant species in the rumen of Korean native goat and secreted considerable amounts of the enzyme into the culture supernatant (Park et al., 1993; Min et al., 1994).

For potential industrial applications, we had previously conducted extensive screening tests to isolate bacterium with high cellulose activity from rumen of Korean native goat (KNG). After a series of experiments, we reported isolation and identification of cellulolytic Antinomyces sp. KNG 40 having the highest cellulolytic activity of isolates tested and characterization of endo- $\beta$-1,4-glucanase (Min et al., 1994a,b). Molecular cloning of novel and powerful cellulase genes might be very important for the successful production and industrial application of the enzyme. For this reason, this study was performed to clone novel and powerful cellulase genes from Antinomies sp. KNG 40 and to characterize purified recombinant cellulase enzyme for industrial applications. To the best of our knowledge, complete molecular cloning, sequencing and biochemical characteristics of cellulase from the Actinomyces have not been reported yet.

Here, we report, for the first time, the cloning and nucleotide sequences analysis of a novel endo- $\beta-1,4-$ glucanase gene from Actinomyces sp. KNG 40 isolated from the rumen of $\mathrm{KNG}$, and the enzyme properties of an endo- $\beta$-1,4-glucanase when expressed in Escherichia coli (E. coli) $\mathrm{DH} 5 \alpha$.

\section{MATERIALS AND METHODS}

\section{Bacterial strains and media}

Ruminal fluid was collected from the rumen of KNGs through a cannula to isolate cellulose-degrading bacteria. The collected ruminal fluid was filtered through cheesecloth and diluted with an anaerobic dilution solution using an anaerobic culture system. The colonies were then isolated by the roll-tube method. Actinomyces sp. KNG 40 was anaerobically grown at $37^{\circ} \mathrm{C}$ on Dehority's artificial medium containing $0.2 \%$ cellobiose. E. coli DH5 $\alpha$ was grown aerobically in Luria-Bertani (LB) medium at $37^{\circ} \mathrm{C}$ or on an LB plate, supplemented with ampicillin $(50 \mu \mathrm{g} / \mathrm{mL})$ for transformants.

\section{Construction of a genomic DNA library and cloning of endoglucanase}

The pUC19 plasmid and E. coli DH5 $\alpha$ were used as the vector-host system for cloning. Chromosomal DNA of Actinomyces sp. KNG 40 was prepared from the cells in the early exponential growth phase following the method of Saito and Miura (1963). Plasmid DNA was prepared by the alkali lysis method (Sambrook et al., 1989). Competent cells of $E$. coli were prepared by the calcium chloride method (Sambrook et al., 1989). Chromosomal DNA of Actinomyces sp. KNG 40 was partially digested with Sau3AI and separated by sucrose density gradient centrifugation $(10 \%$ to $40 \% \mathrm{w} / \mathrm{v})$. DNA fragments of 2 to 8 $\mathrm{kb}$ were collected and ligated into the BamH I site of the pUC19 vector. The ligation products were transformed into competent E. coli $\mathrm{DH} 5 \alpha$, and transformants were selected for by plating on LB agar plates, supplemented with X-gal (5-bromo-4-chloro-3-indolyl-galactoside) and ampicillin at $37^{\circ} \mathrm{C}$ for 12 to $14 \mathrm{~h}$. Clones expressing endoglucanase activity were detected by replica plating the bacterial colonies onto LB containing $0.5 \%$ carboxymethyl cellulose (CMC) and ampicillin. The plates were incubated at $37^{\circ} \mathrm{C}$ for 16 to $24 \mathrm{~h}$. The plates were then flooded with a $0.1 \%$ aqueous solution of Congo red (Sigma, St. Louis, MO, USA) (Teather and Wood, 1982) for $30 \mathrm{~min}$. Unbound dye molecules were removed by reflooding the plates with $1 \mathrm{M}$ $\mathrm{NaCl}$ for $15 \mathrm{~min}$. The formation of visible halos around the colonies indicated the production of endoglucanase.

\section{DNA sequence analysis}

DNA sequences were determined by the chain termination method of Sanger et al. (1997) using a PRISMready reaction dideoxy terminator cycle sequencing kit (Perkin Elmer, Boston, MA, USA) with supercoiled plasmids as templates. The DNA sequences were analyzed using the PC/GENE software package (V. 6.60, IntelliGenetics Inc., Mountain View, CA, USA).

Purification and $\mathrm{N}$-terminal amino acid sequence analysis of an endoglucanase produced by $E$. coli DH5 $\alpha$

An endoglucanase produced by $E$. coli $\mathrm{DH} 5 \alpha$ containing pDS3 was purified by a crystalline cellulose (Avicel PH101; Fluka Chemie GmbH, Buchs, Switzerland) column. The cultured cells were harvested at an early stationary phase by centrifugation at $3,400 \times \mathrm{g}$ for $10 \mathrm{~min}$, and the supernatant was used as a crude enzyme source. The enzyme solution was concentrated using ultrafiltration on an Amicon YM-10 membrane (MW cut-off: 10,000) in an Amicon model 8400 (Millipore, Bedford, MA, USA) stirring ultrafiltration cell under 20 psi of $\mathrm{N}_{2}$. The solution was concentrated by ultrafiltration at each purification step, if necessary. The concentrated enzyme was placed in a crystalline cellulose column (20 mL bed volume) using a BioLogic System (Bio-Rad, Hercules, CA, USA). Bound 
proteins were eluted with double-distilled water and then buffer exchanged into $20 \mathrm{mM}$ Tris-Cl, $\mathrm{pH}$ 7.4. The purified endoglucanase $(3.0 \mu \mathrm{g} / \mathrm{well})$ was separated on a $10 \%$ sodium dodecyl sulfate-polyacrylamide gel electrophoresis minigel at $200 \mathrm{~V}$ using a Bio-Rad Mini-PROTEAN cell. Proteins were electroblotted at $70 \mathrm{~V}$ for $1 \mathrm{~h}$ with water cooling onto a Trans-Blot polyvinylidene fluoride membrane (Bio-RAD Laboratories, USA). The membrane was immersed in $0.025 \%$ Coomassie Blue R-250 for 5 min and destained with $50 \%$ methanol for $15 \mathrm{~min}$. The membrane was then washed with a large volume of distilled water with several changes. The protein band was cut out, and the N-terminal amino acid of the protein was microsequenced using an Edman Gas Phase Microsequencer (Model ALI 473a; Applied Biosystems Inc., Foster city, CA, USA).

\section{Distribution of enzyme}

The fractionations of extracellular, periplasmic, cellbound, and intracellular enzymes were performed as described by the methods of Min et al. (1994a).

\section{Enzyme assays}

Carboxymethyl cellulase (CMCase, endoglucanase) activity was measured as the amount of reducing sugars released from $0.7 \% \mathrm{CMC}$ in a $50 \mathrm{mM}$ sodium citrate buffer $(\mathrm{pH} 6.0)$ at $55^{\circ} \mathrm{C}$ for $30 \mathrm{~min}$. Reducing sugars were measured by the Somogyi-Nelson method (Somogyi, 1952) with glucose as a standard. One unit of enzyme activity was defined as that forming $1 \mu$ mole of glucose equivalent of reducing sugar per minute under the standard conditions. The modified dye-binding method of Bradford (1976) was used for the determination of protein concentrations, with bovine serum albumin as a standard. Enzyme kinetics were studied on a CMC substrate of $0.16 \%$ to $1 \%$ concentration in a $50 \mathrm{mM}$ sodium citrate buffer $(\mathrm{pH} 6.0)$ at $55^{\circ} \mathrm{C}$ for 30 min. From linear plots of the Michaelis-Menten equation such as Lineweaver-Burk or Hanes-Woolf plot using an Excel curve-fitting program (Microsoft Excel 2010, San Francisco, CA, USA), kinetic parameters, $\mathrm{K}_{\mathrm{m}}$ and $\mathrm{V}_{\max }$ of recombinant EG1 was calculated.

Proteins were analyzed by sodium dodecyl sulfatepolyacrylamide gel electrophoresis (SDS-PAGE) using the method of Laemmli (1970). The proteins were stained with Coomassie Brilliant Blue R-250.

\section{RESULTS AND DISCUSSION}

\section{Gene cloning of an endoglucanase from Actinomyces sp. Korean native goat 40}

The genomic library was constructed by ligating 2 to 8 $\mathrm{kb}$ Sau3AI fragments of Actinomyces sp. KNG 40 DNA into the $B a m H I$ site of pUC19. To isolate endoglucanase genes, clones expressing endoglucanase activities were detected by replica plating the bacterial colonies onto an LB (with ampicillin) plate containing $0.5 \%$ CMC. Among the 1,250 clones screened, 10 were identified as endoglucanase positive based on the formation of visible halos around the colonies. Only one of the endoglucanase-positive clones was identified and confirmed as having assayable endoglucanase activities. A recombinant plasmid harboring a $5.0 \mathrm{~kb}$ insert from this clone was designated as pDS1. Various restriction fragments from pDS1 were subcloned into pUC19 vectors, and endoglucanase activity was determined on the $\mathrm{CMC}$ plate. E. coli clones containing pDS3 (3.2 kb insert) showed the highest endoglucanase activity (Figure 1). It has been shown conclusively that most cellulolytic microorganism produces the isomeric forms of cellulase and xylanase with similar substrate specificities, which are the products of large multigene families but not the result of post-translational modification of a single enzyme (Malburg and Forsberg, 1993; Bedford and Partridge, 2001; Nguyen et al., 2012, Rashamuse et al., 2013). Therefore, this clone might be one of multiple cellulase genes from Actinomyces sp. KNG 40.

\section{Nucleotide sequence analysis}

The 2,641 bp fragment of pDS3 was fully sequenced. It contained an open-reading frame of 2,066 bps, starting with ATG and terminating with a TGA stop codon encoding a protein of 688 amino acids, with a calculated molecular mass of 75,753 Da. A putative ribosome-binding site (Shine-Dalgarno sequence) was located 5 bps upstream from the initiation codon (Shine and Dalgano, 1975). CTTGAC and TTATC sequences located at positions 80 and $113 \mathrm{nt}$, respectively, upstream from the Shine-Dalgarno sequence corresponded to the putative utative ns 80 and 113ion of a single A putative catalytic domain and a cellulose-binding domain were found between 872 and 1,851 and between 1,920 and 2,252, respectively, the domains were connected by a Ser- and a Thr-rich linker region between 1,852 and 1,919. Comparison of the deduced amino acid sequence of the endoglucanase gene with that of other endoglucanases compiled in GenBank revealed sequence homology to family 5 (family A) glycosyl hydrolases (Table 1). Genes encoding for cellulase enzymes from a variety of rumen bacteria have been cloned

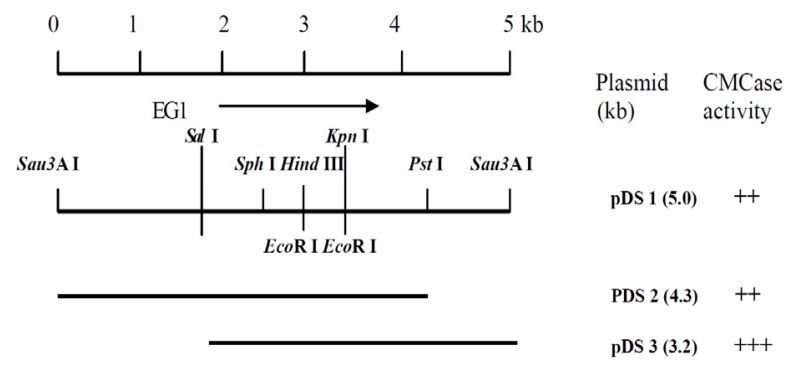

Figure 1. Mapping and subcloning of the cloned endo- $\beta-1,4-$ glucanase gene ( $p D S 1)$. 
and sequenced, and their amino acid sequences have been deduced (Pollle et al., 1990; Mittendorf et al., 1993; Cho et al., 2000; Nguyen et al., 2012). However, to our knowledge, molecular cloning, sequence analysis and characterization of cellulase gene from anaerobic rumen bacterium Actinomyce sp., has not been reported so far. This is the first report of the cloning and sequence analysis of an endoglucanase gene from rumen bacterium Actinomyce sp. No DNA sequence similarity was identified with the published endoglucanase from a variety of bacteria. The GenBank accession number of the cloned endoglucanase is U94825.

\section{Purification and N-terminal sequence analysis of endoglucanase produced by $\boldsymbol{E}$. coli $\mathrm{DH} 5 \alpha$}

Fungal cellulases are usually released from the cell (Areej et al., 2014). Although generally bacterial enzymes seem to remain with cell, cellulases from some of anaerobic rumen bacteria may be secreted by the cell (Clarke, 1997). For examples, endoglucanases from some rumen bacteria including Clostridium sp., Fibrobacter succinogenes, and Bacillus licheniformis were reported to be secreted into the culture medium (Mittendorf and Thomson, 1993; Cho et al., 2000; Seo et al., 2013). In this study, two-thirds of the endoglucanase enzyme was secreted into the Actinomyces culture medium. About $40 \%$ of the recombinant enzyme was fully secreted into the culture medium when it was expressed in E. coli containing pDS3 (Table 2). It means that the secretion ability of the signal peptide of the endoglucanase is more powerful than others, and the secreted recombinant enzyme in E.coli can be used in many industrial applications including animal feed industry (Kuhad et al., 2011; Gao et al., 2015). A recombinant endoglucanase EG1 was purified from the culture medium of E. coli DH5 $\alpha$ containing $\mathrm{pDS} 3$ in one step in a microcrystalline cellulose (Avicel PH-101; Fluka Chemie

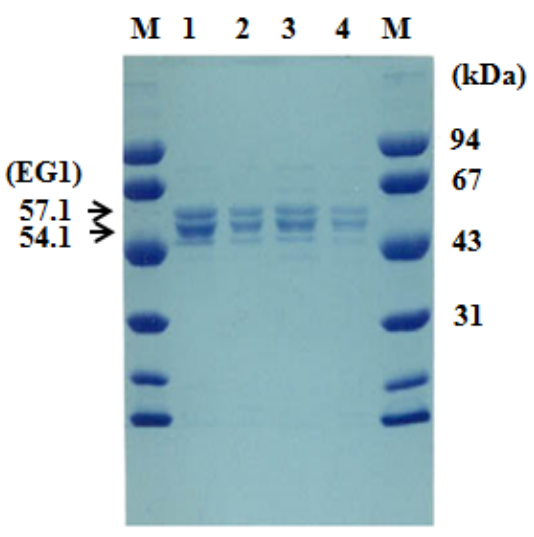

Figure 2. SDS-PAGE of EG1. The gel was stained with Coomassie Blue R250. Endoglucanase (EG1) was identified using an MUC zymogram assay (data not shown). M, Protein molecular markers; lane $1(10 \mu \mathrm{L})$ and lane $2(2 \mu \mathrm{L})$ from fraction E1 and lane $3(10 \mu \mathrm{L})$ and lane $4(2 \mu \mathrm{L})$ from fraction E2 of the microcrystalline cellulose column eluent. SDS-PAGE, sodium dodecyl sulfate-polyacrylamide gel electrophoresis.

$\mathrm{GmbH}$, Buchs, Switzerland) column. The specific activity of the purified EG1 was $56.7 \mathrm{U} / \mathrm{mg}$ protein.

The SDS-PAGE/zymogram technique using the fluorogenic substrate methylumbelliferyl cellobioside (MUC) was used to separate and detect two major band showing endoglucanase activity from the purified enzyme. An active protein bands having an approximate molecular weight (MW) of 51.4 and $57.1 \mathrm{kDa}$, respectively, were detected on Laemmli gel under UV illumination (data not shown) (Figure 2). The ratio of the activity and the protein band intensity of the two bands were very similar.

The N-terminal sequences of these two bands analyzed by Edman degradation method matched those of the deduced sequences, starting from residue 166 and 208, respectively (Figure 3). The cleavage site of the recombinant endoglucanase by signal peptidase obey the

Table 1. Comparison of the amino acid sequences of the endoglucanase in this study with those various family 5 endoglucanases ${ }^{1}$

\begin{tabular}{llcccc}
\hline Protein & Species & Family & Identity (\%) & Positivity (\%) & GenBank No. \\
\hline Endoglucanase & Fibrobacter succinogenes & 5 & 67 & 80 & U94826 \\
& Clostridium saccharobutylicum & 5 & 43 & 59 & P15704 \\
& Bacillus subtilis DLG & 5 & 40 & 57 & A26874 \\
& Bacillus amyloliquefaciens & 5 & 41 & 58 & AF363635 \\
& Ruminococcus albus & 5 & 42 & 61 & AB016777 \\
& Clostridium acetobutylicum & 5 & 37 & 55 & AE007585 \\
\hline
\end{tabular}

${ }^{1}$ The comparison of the amino acid sequences was performed with the NCBI's BLAST program.

Table 2. Localization of endo- $\beta$-1,4-glucanase activity (in \%) in Actinomyces sp. Korean native goat 40 and Escherichia coli (E. coli) DH5 $\alpha$

\begin{tabular}{lccccc}
\hline \multirow{2}{*}{ Host } & \multicolumn{5}{c}{ Fraction } \\
\cline { 2 - 5 } & Extracelluar & Periplasmic & Cytoplasmic & Cell-bound & Total activity \\
\hline Actinomyces & 67.7 & 11.3 & 10.5 & 10.5 & 100 \\
E. coli & 39.8 & 18.7 & 31.8 & 9.6 & 100 \\
\hline
\end{tabular}




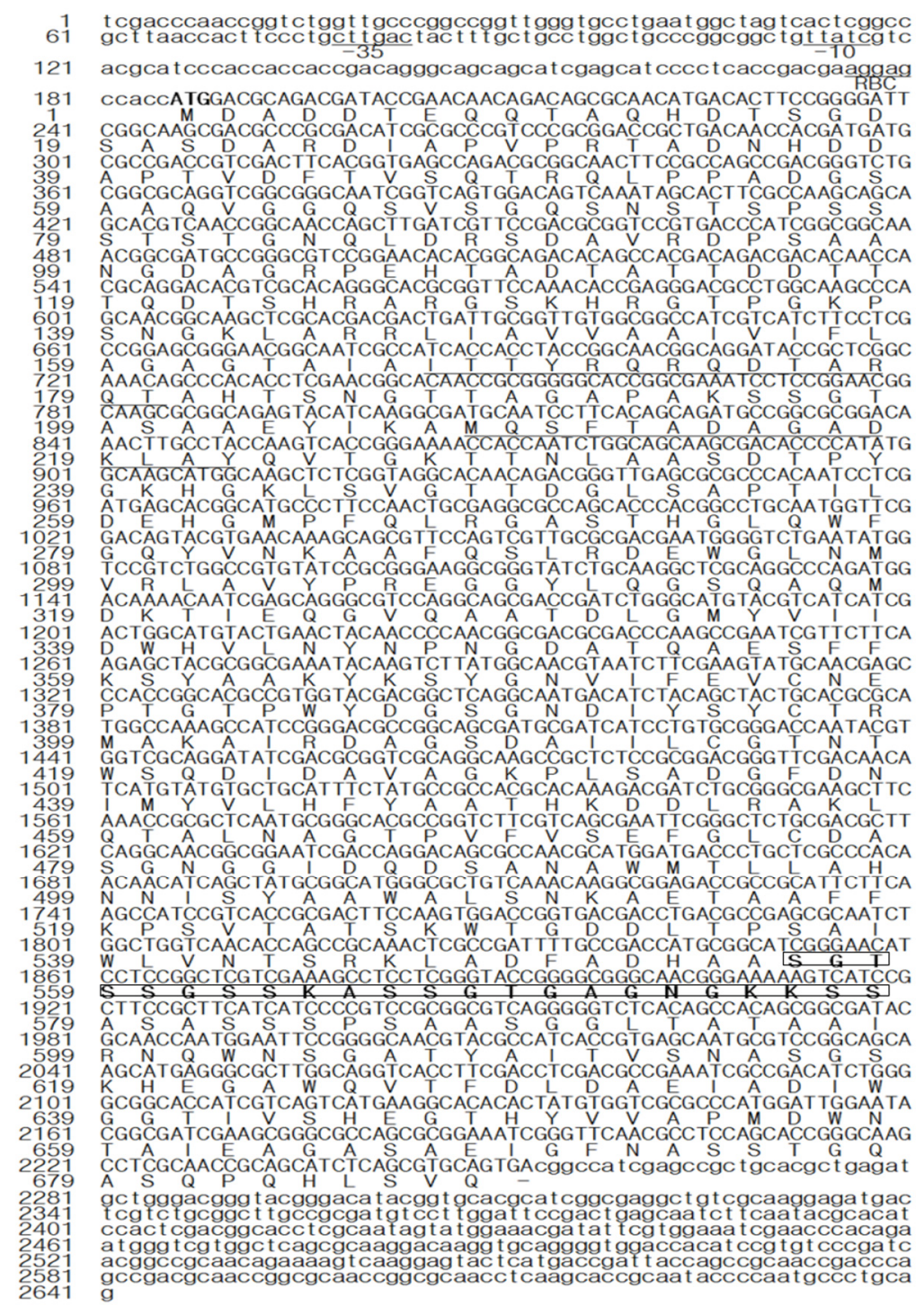

Figure 3. Nucleotide sequence of the 2,641 bp Sal I/Pst I restriction fragment of pDS3. The putative promoter sequence and ribosomebinding site are underlined. The deduced amino acid sequence for the endoglucanase is shown under the nucleotide sequence. Two amino terminal sequences determined for the recombinant endoglucanase are underlined. The Ser- and Thr-rich linker region is shown in the box.

"(-3,-1) rule": the residue at position -1 must be small and uncharged (Ala, Ser, Gly, Cys, Thr, Gln, Pro, or Leu), and also the residue at position -3 is always a small and uncharged (Ala, Ser, Gly, Cys, Thr, Ile, Leu, or Val) (Perlman and Halvorson, 1983; Von Heijne, 1985; Yan and $\mathrm{Wu}, 2014)$. It indicates that these preceding amino acids play a signal peptide-like role. The cellulose-binding domain starts from residue 166 or 208.

\section{Characterization of purified endoglucanase produced by E. coli DH5a}

Table 3 shows the substrate specificity of endoglucanase. Many studies have reported that a large number of cloned cellulases from rumen bacteria possess bifunctional endoglucanase-xylanase activities (Cho et al., 2000; Chang et al., 2011; Rashamuse et al., 2013; Yuan et al., 2015). The purified endoglucanase from our study showed the highest enzyme activity against CMC but weak enzyme activity was observed for xylan, avicell, and cellobiose (Table 3).

Table 3. Substrate specificity of endoglucanase from Escherichia coli $\mathrm{DH} 5 \alpha$ harboring pDS3

\begin{tabular}{lc}
\hline Substrate & Relative activity (\%) \\
\hline Carboxymethyl cellulose $^{1}$ & 100 \\
Xylan $^{1}$ & 6.1 \\
Avicell $^{1}$ & 8.1 \\
Cellobiose $^{2}$ & 26 \\
\hline
\end{tabular}

${ }^{1}$ Enzyme activity was measured as the amount of reducing sugars released.

${ }^{2}$ Enzyme activity was calculated from the amount of glucose released and divided by two. 
This result is consistent with previous studies of Actinomyces sp. (Min et al., 1994).

The optimum temperature of the enzyme activity was determined by assaying the endoglucanase activities at various temperatures for $30 \mathrm{~min}$ in a $50 \mathrm{mM}$ sodium citrate buffer ( $\mathrm{pH} 6.0$ ) with $0.7 \% \mathrm{CMC}$. The optimal temperature of the purified enzyme was $55^{\circ} \mathrm{C}$, but it retained over $90 \%$ of maximum activity in a broad temperature range $\left(40^{\circ} \mathrm{C}\right.$ to $60^{\circ} \mathrm{C}$ ). The enzyme activity decreased rapidly above $65^{\circ} \mathrm{C}$ but the enzyme still retained $60 \%$ of its maximum activity even at $70^{\circ} \mathrm{C}$ (Figure 4). In general, endoglucanases from fungi and bacteria are stable at temperature below $55^{\circ} \mathrm{C}$ (Ohara et al., 2000; Nguyen et al., 2012; Culleton et al., 2014). This result suggests that the cloned endoglucanase from Actinomyces sp. KNG 40 is more thermostable and active at high temperature.

The effects of $\mathrm{pH}$ on the activity were determined by varying the $\mathrm{pH}$ of the reaction mixture using a $50 \mathrm{mM}$ sodium citrate buffer (pH 3.0 to 6.0 ) and $50 \mathrm{mM}$ sodium phosphate buffer (pH 6.0 to 8.0 ) with $0.7 \% \mathrm{CMC}$ at $45^{\circ} \mathrm{C}$ for $30 \mathrm{~min}$. The optimal $\mathrm{pH}$ for the enzyme activity was 6.0 (Figure 5). This result is consistent with previous reports. Many studies have reported that the optimal $\mathrm{pH}$ for the cloned endoglucanases activity from various cellulolytic rumen bacteria was in the range of $\mathrm{pH} 5.0$ to 7.0 (Cho et al., 2000; Gong et al., 2012; Nguyen et al., 2012). The enzyme kinetic parameters were measured in a $50 \mathrm{mM}$ sodium citrate buffer ( $\mathrm{pH} 6.0)$ at $55^{\circ} \mathrm{C}$ for $30 \mathrm{~min}$. From linear plots of the Michaelis-Menten equation such as Lineweaver-Burk or Hanes-Woolf plot using an Excel curve fitting program, the $\mathrm{K}_{\mathrm{m}}$ and $\mathrm{V}_{\max }$ of recombinant EG1 was calculated: In Lineweaver-Burk plot $\left(\mathrm{R}^{2}=0.9998\right) \mathrm{Km}$ and Vmax were $0.4 \% \mathrm{CMC}$ and $144.9 \mathrm{U} / \mathrm{mg}$, respectively. In Hanes-Woolf plot $\left(\mathrm{R}^{2}=0.9997\right)$ they were $0.39 \% \mathrm{CMC}$ and $143 \mathrm{U} / \mathrm{mg}$, respectively.

In conclusion, we have successfully cloned a novel endo- $\beta$-1,4-glucanase gene from cellulolytic rumen Actinomyces sp. KNG 40 bacterium into Excherichia coli,

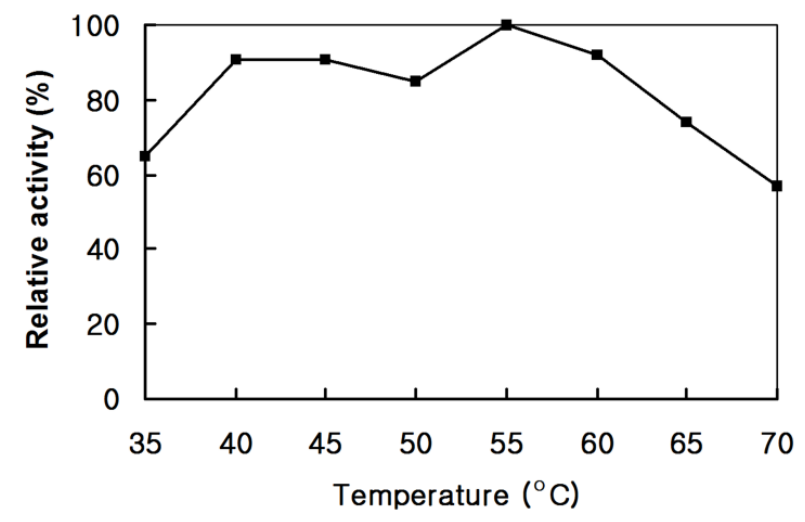

Figure 4. Temperature-activity profile of the endoglucanase. The assay was performed for $30 \mathrm{~min}$ in a $50 \mathrm{mM}$ sodium citrate buffer (pH 6.0) with $0.7 \%$ carboxyl methyl-cellulose.

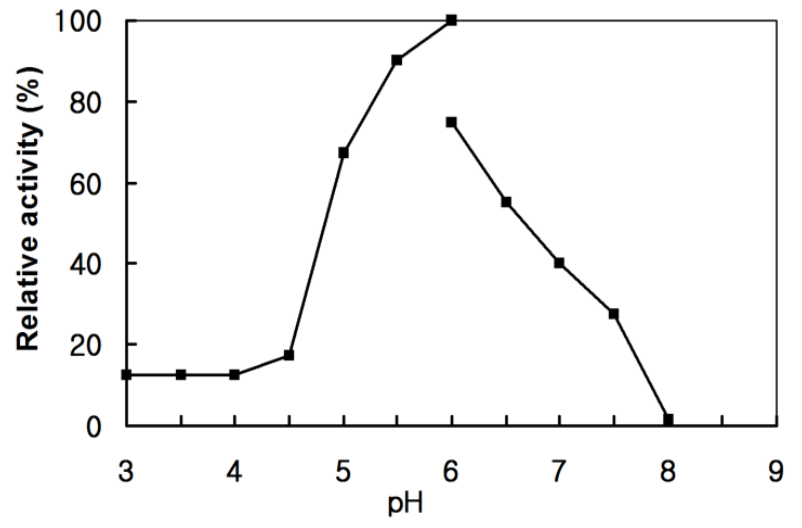

Figure 5. Effect of the $\mathrm{pH}$ on the endoglucanase. The assay was performed at $55^{\circ} \mathrm{C}$ for $30 \mathrm{~min}$ in a $50 \mathrm{mM}$ sodium citrate buffer (pH 3.0 to 6.0 ) and $50 \mathrm{mM}$ sodium phosphate buffer $(\mathrm{pH} 6.0$ to 8.0 ) with $0.7 \%$ carboxyl methyl-cellulose.

and analyzed nucleotide sequences and the enzymatic properties of the cloned endoglucanase. The cloned endoglucanase is more thermostable than enzymes produced by other rumen bacteria, and has powerful signal sequences for secretion of the enzyme into culture medium. Therefore, this recombinant endoglucanase may be a good candidate to be used in livestock feed as an additive to increase the digestibility of feedstuff for non-ruminant animal, and in the other industry.

\section{CONFLICT OF INTEREST}

We certify that there is no conflict of interest with any financial organization regarding the material discussed in the manuscript.

\section{ACKNOWLEDGMENTS}

This work was financially supported by Priority Research Centers Program (No. 2009-0093813 to K. K. Cho) and by Basic Science Research Program (No. NRF2013R1A1A2011997 to S. C. Kim) through the National Research Foundation of Korea (NRF) funded by the Ministry of Education, Science and Technology.

\section{REFERENCES}

Areej, A., E. M. Altenaiji, and L. F. Yousef. 2014. Fungal cellulases from mangrove forests - A short review. J. Biochem. Tech. 5:765-774.

Baird, S. D., D. A. Johnson, and V. L. Seligy. 1990. Molecular cloning, expression, and characterization of endo-beta-1,4glucanase genes from Bacillus polymyxa and Bacillus circulans. J. Bacteriol. 172:1576-1586.

Bedford, M. R. and G. G. Partridge. 2001. Enzymes in Farm Animal Nutrition. CABI publishing. Wallingford, Xofrodshire, UK. 38 p. 
Bradford, M. M. 1976. A rapid and sensitive method for the quantification of microgram quantities of protein utilizing the principle of protein dye binding. Anal. Biochem. 72:248-254.

Chang, L., M. Ding, L. Bao, Y. Chen, J. Zhou, and H. Lu. 2011. Characterization of a bifunctional xylanase/endoglucanase from yak rumen microorganisms. Appl. Microbiol. Biotechnol. 90:1933-1942.

Clarke. A. J. 1997. Biodegradation of Cellulose: Enzymology and Biotechnology. A Technomic Publishing Company Book, Lancaster, PA, USA. 43 p.

Cho, K. K., S. C. Kim, J. J. Woo, J. D. Bok, and Y. J. Choi. 2000. Molecular cloning and expression of a novel family A endoglucanase gene from Fibrobacter succinogenes S85 in Escherichia coli. Enzyme Microb. Technol. 27:475-481.

Coughlan, M. P. 1985. The properties of fungal and bacterial cellulases with comment on their production and application. Biotechnol. Genet. Eng. Rev. 3:39-110.

Culleton, H., V. A. McKie, and R. P. de Vries. 2014. Overexpression, purification and characterisation of homologous $\alpha$-L-arabinofuranosidase and endo-1,4- $\beta$-Dglucanase in Aspergillus vadensis. J. Ind. Microbiol. Biotechnol. 41:1697-1708.

Forsberg, C. W., J. Gong, L. M. J. Malburg, H. Zhu, A. Iyo, K. J. Cheng, P. J. Krell, and J. P. Phillips. 1993. Preceedings of MIE Bioforum 93: Genetics, Biochemistry and Ecology of Lignocellulose Degradation. Toba, Japan. 125-136.

Gao, D., Y. Luan, Q. Wang, Q. Liang, and Q. Qi. 2015. Construction of cellulase-utilizing Escherichia coli based on a secretable cellulase. Microb. Cell Fact. 14:159-167.

Gilkes, N. R., B. Henrissat, D. G. Kildrun, R. C. Miller, and R. A. J. Warren. 1991. Domains in microbial $\beta$-1, 4-glycanases: Sequence conservation, function, and enzyme families. Microbiol. Mol. Biol. Rev. 55:303-315.

Gong, X., R. J. Gruninger, M. Qi, L. Paterson, R. J. Forster, R. M. Teather, and T. A. McAllister. 2012. Cloning and identification of novel hydrolase genes from a dairy cow rumen metagenomic library and characterization of a cellulase gene. BMC Res. Notes. 5:566-576.

Kuhad, R. C., R. Gupta, and A. Singh 2011. Microbial cellulases and their industrial applications. Enzyme Res. Article ID 280696.

Laemmli, U. K. 1970. Cleavage of structural proteins during the assembly of the head of bacteriophage T4. Nature 227:680-685.

Lee, D. S. and M. Y. Pack. 1988. Use of Bacilli for overproduction of exocellular endo-beta-1,4-glucanase encoded by cloned gene. Enzyme Microb. Technol. 9:594-597.

Lemaire, M. and P. Beguin. 1993. Nucleotide sequence of the celG gene of Clostridium thermocellum and characterization of its product, endoglucanase CelG. J. Bacteriol. 175:3353-3360.

Mackay, R. M., A. Lo, G. Willick, M. Zuker, S. Baird, M. Dove, F. Moranelli, and V. Seligy. 1986. Structure of a Bacillus subtilis endo-beta-1, 4-glucanase gene. Nucl. Acids Res. 14:9159-9170.

Malburg, L. M. Jr. and C. W. Forsberg. 1993. Fibrobacter succinogenes prossesses at least nine distinct glucanase genes. Can. J. Microbiol. 39:882-891.

Min, H. K., Y. J. Choi, J. K. Ha, K. K. Cho, Y. M. Kwon, Y. H. Chang, and S. S. Lee. 1994a. Isolation and identification of anaerobic rumen bacterium, Actinomyces sp. 40 and enzymatic properties of $\beta$-1,4-glucanase. Asian Australas. J. Anim. Sci.
7:373-382.

Min, H. K., Y. J. Choi, K. K. Cho, J. K. Ha, and J. H. Woo. 1994b. Cloning of the endoglucanase gene from Actinomyces sp. 40 in Escherichia coli and some properties of the gene products. J. Microbiol. Biotechnol. 4:102-107.

Mittendorf, V. and J. A. Thomson. 1993. Cloning of an endo(10>4)-betaglucanase gene, celA, from the rumen bacterium Clostridium sp. ('C.longisporum') and characterization of its product. CelA, in Escherichia coli. J. Gen. Microbiol. 139:3233-3242.

Miyatake, M. and K. Imada. 1997. A gene encoding endo-1,4beta-glucanase from Bacillus sp. 22-28. Biosci. Biotechnol. Biochem. 61:362-364.

Nguyen, N. H., L. Maruset, T. Uengwetwanit, W. Mhuantong, P. Harnpicharnchai, V. Champreda, S. Tanapongpipat, K. Jirajaroenrat, S. K. Rakshit, L. Eurwilaichitr, and S. Pongpattanakitshote. 2012. Identification and characterization of a cellulase-encoding gene from the buffalo rumen metagenomic library. Biosci. Biotechnol. Biochem. 76:10751084.

Ohara, H., J. Noguchi, S. Karita, T. Kimura, K. Sakka, and K. Ohmiya. 2000. Sequence of $\mathrm{egV}$ and properties of $\mathrm{EgV}$, a Ruminococcus albus endoglucanase containing a dockerin domain. Biosci. Biotechnol. Biochem. 64:80-88.

Park, K. M., H. T. Shin, and K. H. Kang. 1993. Isolation and identification of rumen bacteria from Korean native goat. I. Isolation and identification of Gram positive bacteria. Kor. J. Dairy Sci. 15:165-177.

Perlman, D. and H. O. Halvorson. 1983. A putative signal peptidase recognition site and sequence in eukaryotic and prokaryotic signal peptides. J. Mol. Biol. 167:391-409.

Poole, D. M., G. P. Hazlewood, J. I. Laurie, P. J. Barker, and H. J. Gilbert. 1990. Nucleotide sequence of the Ruminococcus albus SY3 endoglucanase genes celA and celB. Mol. Gen. Genet. 223:217-223.

Rashamuse, K. J., D. F. Visser, F. Hennessy, J. Kemp, M. P. Rouxvan der Merwe, J. Badenhorst, T. Ronneburg, R. Francis-Pope, and D. Brady. 2013. Characterisation of two bifunctional cellulase-xylanase enzymes isolated from a bovine rumen metagenome library. Curr. Microbiol. 66:145-151.

Sahu, N. P., D. N. Kamra, and S. S. Paul. 2004. Effect of cellulose degrading bacteria isolated from wild and domestic ruminants on in vitro dry matter digestibility of feed and enzyme production. Asian Australas. J. Anim. Sci. 17:199-202.

Saito, H. and K. Miura. 1963. Preparation of transforming deoxyribonucleic acid by phenol treatment. Biochim. Biophys. Acta. Specialized Section on Nucleic Acids and Related Subjects 72:619-629.

Sambrook, J., E. F. Fritsch, and T. Maniatis. 1989. Molecular cloning: A laboratory manual, 2nd Ed. Cold Spring Harbour Laboratory Press. Cold Spring Harbor, NY, USA.

Sanger, R., S. Niclien, and A. R. Coulson. 1997. DNA sequencing with chain terminating inhibitors. Proc. Natl. Acad. Sci. 74:5463-5467.

Seo, J. K., T. S. Park, I. H. Kwon, M. Y. Piao, C. H. Lee, and J. K. Ha. 2013. Characterization of cellulolytic and xylanolytic enzymes of Bacillus licheniformis JK7 isolated from the rumen of a native Korean goat. Asian Australas. J. Anim. Sci. 26:5058 . 
Shine, J. and L. Dalgano. 1975. Determinant of cistron specificity in bacterial ribosomes. Naure 254:34-38.

Somogyi, M. 1952. Notes on sugar determination. J. Biol. Chem. 195:19-23.

Teather, R. M. and P. J. Wood. 1982. Use of Congo red polysaccharide interactions in enumeration and characterization of celluloytic bacteria from the bovine rumen. Appl. Environ. Microbiol. 43:777-780.
Von Heijne, G. 1985. Signal sequences: The limits of variation. J. Mol. Biol. 184:99-105.

Yan, S. and G. Wu. 2014. Signal peptide of cellulase. Appl. Microbiol. Biotechnol. 98:5329-5362.

Yuan, S. F., T. H. Wu, H. L. Lee, H. Y. Hsieh, W. L. Lin, B. Yang, C. K. Chang, Q. Li, J. Gao, C. H. Huang, M. C. Ho, R. T. Guo and P. H. Liang. 2015. Biochemical characterization and structural analysis of a bifunctional cellulase/xylanase from Clostridium thermocellum. J. Biol. Chem. 290:5739-5748. 